\title{
RANCANG BANGUN SISTEM INFORMASI LAPORAN REALISASI PENGADAAN BARANG DAN JASA BERBASIS WEB
}

\author{
${ }^{1}$ Rahmat Gunawan*, ${ }^{2}$ Eva Wulan Ndari, ${ }^{3}$ Meiniarti \\ 1,2,3 Program Studi Manajemen Informatika, STMIK Rosma \\ Jl. Kertabumi No.62, Karawang Kulon, Kec. Karawang Barat., Kabupaten Karawang, Jawa Barat \\ 41311 \\ *e-mail: rahmat@rosma.ac.id
}

Received: 2021-08-24, Revised: 2021-08-28, Accepted: 2021-09-02

\begin{abstract}
Abstrak
Pemerintah Daerah Kabupaten Karawang merupakan sebuah lembaga pemerintah daerah merujuk pada otoritas administratif di suatu daerah yang lebih kecil dari sebuah negara dan didalamnya terdapat beberapa bagian seperti bagian perkenomian, bagian administrasi pembangunan, bagian kesra, dan bagian pengadaan barang dan jasa. Kegiatan administratif di pemerintah daerah kabupaten karawang tidak bisa terlepas dari adanya pembuatan berkas laporan yang biasanya ditujukan untuk bukti adanya suatu kegiatan. Salah satu kegiatan yang dilakukan bagian pengadaan barang dan jasa adalah pengadaan barang dan jasa dimana setiap selesai suatu projek akan menghasilkan sebuah laporan yang disebut dengan laporan pengadaan barang dan jasa. Dengan adanya sistem informasi untuk mempermudah dalam pencarian dan penyajian laporan realisasi barang dan jasa, serta menyimpan berkas laporan realisasi pengadaan barang dan jasa, dapat mempermudah admin dalam pencarian, penyajian, dan menyimpan berkas laporan realisasi pengadaan barang dan jasa. Sistem informasi ini dibuat menggunakan metode pengembangan sistem waterfall dengan bahasa pemrograman PHP dan HTML serta menggunakan basis data MYSQL.
\end{abstract}

Kata kunci: Sistem Informasi, Pengadaan Barang dan Jasa, Web

\section{Abstract}

The Regional Government of Karawang Regency is a local government institution referring to the administrative authority in an area smaller than a country and in it there are several sections such as the economic section, the development administration section, the welfare section, and the goods and services procurement section. Administrative activities in the local government of Karawang Regency cannot be separated from the preparation of report files which are usually intended to prove the existence of an activity. One of the activities carried out by the procurement of goods and services is the procurement of goods and services where every time a project is completed it will produce a report called a report on the procurement of goods and services. With the existence of an information system to make it easier to search and present reports on the realization of goods and services, as well as save the report file on the realization of the procurement of goods and services, it can make it easier for admins to search, present, and store the report file on the realization of the procurement of goods and services. This information system is made using the waterfall system development method with PHP and HTML programming languages and uses the MYSQL database.

Keywords: Information Systems, Procurement of Goods and Services, Web

\section{PENDAHULUAN (Introduction)}

Pemerintah Daerah Kabupaten Karawang merupakan sebuah Lembaga pemerintah daerah merujuk pada otoritas administratif di suatu daerah yang lebih kecil dari sebuah negara dan 
didalamnya terdapat beberapa bagian seperti bagian perekonomian, bagian administrasi pembangunan, bagian kesra, dan bagian pengadaan barang dan jasa. Kegiatan administratif di Pemerintah Daerah Kabupaten Karawang tidak bisa terlepas dari adanya pembuatan berkas laporan yang biasanya ditujukan untuk bukti adanya suatu kegiatan. Di Pemerintah Daerah Kabupaten Karawang terdapat bagian pengadaan barang dan jasa yang bertugas untuk mengolah beberapa bentuk pengadaan seperti pengadaan konsultan, pengadaan konstruksi, pengadaan barang, dan pengadaan jasa lainnya. Salah satu kegiatan yang dilakukan bagian pengadaan barang dan jasa adalah pengadaan barang dan jasa setiap selesai suatu projek akan menghasilkan sebuah laporan yang disebut dengan laporan pengadaan barang dan jasa.

Setiap selesai membuat laporan admin bagian pengadaan barang dan jasa menyimpan berkas laporan pengadaan barang dan jasa pada penyimpanan internal. Namun karena hal tersebut maka timbul permasalahan seperti dalam hal belum ada tempat penyimpanan berkas laporan realisasi pengadaan barang dan jasa, dan administrator sering kesulitan dalam proses pencarian data laporan realisasi pengadaan barang dan jasa karena laporan tersebut disimpan di lemari secara tidak berurutan sehingga menyebabkan keterlambatan dalam penyajian laporan realisasi pengadaan barang dan jasa.

Untuk mempermudah dalam menyimpan berkas laporan realisasi pengadaan barang dan jasa serta pencarian dan penyajian laporan realisasi pengadaan barang dan jasa, perlu dirancang suatu sistem informasi yang dapat mempermudah admin dalam menyimpan, pencarian, dan penyajian berkas laporan realisasi pengadaan barang dan jasa. sistem informasi ini diharapkan dapat menggantikan cara menyimpan berkas laporan pengadaan barang dan jasa. oleh sebab itu, dalam skripsi ini penulis akan membuat sistem informasi untuk menangani masalah penyimpanan, penyajian, dan pencarian laporan realisasi pengadaan barang dan jasa.

Berdasarkan uraian latar belakang di atas maka peneliti mengambil judul system informasi laporan realisasi pengadaan barang dan jasa berbasis web(Studi Kasus di Pemerintah Daerah Kabupaten Karawang bagian Pengadaan Barang dan Jasa) merupakan sistem informasi untuk menangani masalah penyimpanan, penyajian, dan pencarian laporan realisasi pengadaan barang dan jasa.

\section{TINJAUAN LITERATUR (Literature Review)}

\subsection{Sistem Informasi}

Analisis dan Perancangan Sistem Informasi Menggunakan Model Terstruktur dan UML [1] sistem informasi merupakan suatu kumpulan dari komponen-komponen dalam organisasi yang berhubungan dengan proses penciptaan aliran informasi.

Kualitas Penerapan Sistem Informasi Akuntansi Manajemen Pada Entitas Sektor Publik [2] sistem informasi yaitu suatu kegiatan yang di dalamnya terjadi pengumpulan, pemrosesan, penyimpanan, analisis, dan menyebarkan informasi demi tercapainyna suatu tujuan.

Berdasarkan pendapat diatas, penulis menyimpulkan sistem informasi adalah rangkaian prosedur kerja, informasi, orang dan teknologi di mana data dikelompokan, diproses menjadi informasi serta didistribusikan untuk mencapai tujuan dalam sebuah organisasi.

\subsection{E-Government}

E-government atau kadang sering disingkat menjadi e-gov adalah istilah yang menyatakan penggunaan teknologi informasi untuk melakukan transformasi hubungan dengan masyarakat, bisnis, sesama badan pemerintah, dan pegawai.[3]

Menurut Instruksi Presiden Nomor 3 Tahun 2003, strategi pengembangan egovernment adalah sebagai berikut.

1. Mengembangkan sistem pelayanan yang andal dan terpercaya, serta terjangkau oleh masyarakat luas.

2. Menata sistem manajemen dan proses kerja pemerintah dan pemerintah daerah otonom secara holistik. 
DOI: $10.52362 / j m i j a y a k a r t a . v 1 i 4.547$

3. Memanfaatkan teknologi informasi secara optimal.

4. Meningkatkan peran serta dunia usaha dan mengembangkan industri telekomunikasi dan teknologi informasi.

5. Mengembangkan kapasitas sumber daya manusia baik pada pemerintah maupun pemerintah daerah otonom, disertai dengan meningkatkn e-literacy masyarakat.

6. Melaksanakan pengembangan secara sistematik melalui tahapan-tahapan yang realistik dan terukur.

\subsection{Basis Data}

Basis data adalah media untuk menyimpan data agar dapat diakses dengan mudah dan cepat. [4]

Basis data atau database adalah suatu pengorganisasian sekumpulan data yang saling terkait sehingga memudahkan aktivitas untuk memperoleh informasi.[3]

\subsection{MySQL}

mysql adalah sebuah sistem manajemen database relasi (Relational Database Management System) yang bersifat "terbuka" (open source). Terbuka maksudnya adalah mysql dapat didownload oleh siapa saja. [5]

mysql adalah salah satu jenis database server yang sangat terkenal dan banyak digunakan untuk membangun aplikasi web yang menggunakan database sebagai sumber dan pengolahan datanya.[6]

\subsection{Web}

Website atau disingkat web dapat diartikan sekumpulan halaman yang terdiri dari beberapa laman yang berisi informasi dalam bentuk data digital baik berupa text, gambar, video, audio, dan animasi lainnya yang disediakan melalui jalur koneksi internet. [7]

Sistem pengaksesan informasi dalam internet yang paling dikenal adalah World Wide Web (WWW) atau biasa dikenal dengan istilah web. Pertama kali diciptakan pada tahun 1991 di CERN, Laboratorium Fisika Partikel Eropa, Jenewa, Swiss. Tujuan awalnya adalah untuk menciptakan media yang mudah untuk berbagai informasi di antara para fisikawan dan ilmuwan.[8]

\subsection{PHP}

PHP merupakan skrip yang berjalan di server dan sangat populer di lingkungan Linux. Saat ini, PHP dapat berjalan pada berbagai platform, dari UNIX hingga Windows. [9]

PHP adalah bahasa scripting server dan alat yang ampuh untuk membuat halaman web dinamis dan interaktif.[10]

\subsection{Bootstrap}

Bootsrtrap adalah front-end framework yang bagus dan luar biasa yang mengedepankan tampilan untuk mobiledevice (handphone, smartphone, d.ll) guna mempercepat dan mempermudah pengembangan website.[11]

Bootsrtrap merupakan salah satu framework HTML, CSS, dan JS yang cukup banyak digunakan oleh para pengembang web.[12]

\subsection{Pengertian Metode Waterfall}

Model waterfall adalah model klasik yang bersifat sistematis, berurutan dalam membangun software. Nama model ini sebenarnya adalah "Linear Sequential Model". Model ini sering disebut juga dengan "classic life cycle" atau metode waterfall. Model ini termasuk ke dalam model generic pada rekayasa 
DOI: $10.52362 / j m i j a y a k a r t a . v 1 i 4.547$

perangkat lunak dan pertama kali diperkenalkan oleh Winston Royce sekitar tahun 1970 sehingga sering dianggap kuno, tetapi merupakan model yang paling banyak dipakai dalam Software Engineering (SE). Model ini melakukan pendekatan secara sistematis dan berurutan. Disebut dengan waterfall karena tahap demi tahap yang dilalui harus menunggu selesainya tahap sebelumnya dan berjalan berurutan.

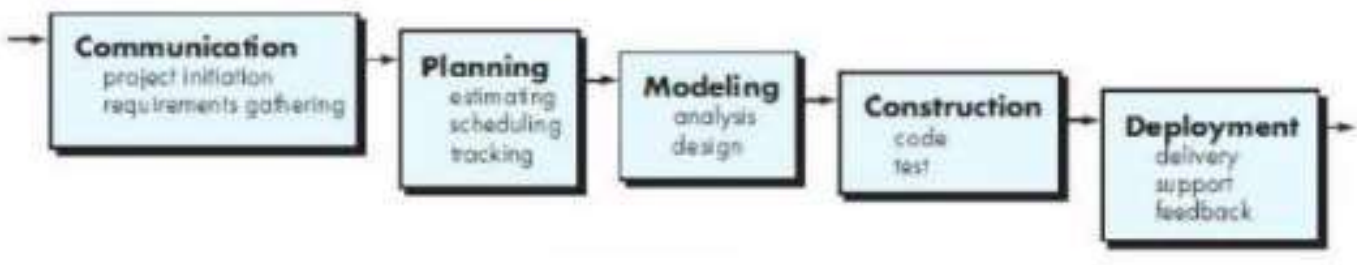

Gambar 1. Model Waterfall

\subsection{UML (Unified Modeling Language)}

Unified Modeling Language (UML) versi 2.0 adalah sekumpulan konversi pemodelan yang digunakan untuk menentukan atau menggambarkan sebuah sistem software yang terkait dengan objek.

UML mulai diperkenalkan oleh Object Management Group, sebuah organisasi yang telah mengembangkan model, teknologi, dan standar OOP sejak tahun 1980-an. Sekarang, UML sudah mulai banyak digunakan oleh para praktisi OOP. UML juga merupakan dasar bagi design tools berorientasi objek pada IBM.

UML dikembangkan sebagai suatu alat untuk analisis dan desain berorientasi objek oleh Grady Booch, Jim Rumbaugh, dan Ivar Jacobson.[13]

UML menyediakan tiga belas macam diagram untuk memodelkan aplikasi berorientasi objek, empat macam diagram yang akan digunakan dalam penelitian ini yaitu:

1. Use case diagram menggambarkan interaksi antara sistem internal, system eksternal, dan user. Dengan kata lain, secara grafik menjelaskan siapa yang menggunakan sistem, dan dengan cara apa user berinteraksi dengan sistem.

2. Activity diagram menggambarkan alur sequential dari aktivitas sebuah proses bisnis atau use case. Bisa juga digunakan untuk memodelkan logika yang digunakan sistem.

3. Class diagram menggambarkan struktur objek sistem. Menunjukkan kelas yang menjadi komponen dari sistem, serta hubungan antar kelas.

4. Sequence diagram menggambarkan bagaimana objek berinteraksi melalui pengiriman pesan (message) dalam pengeksekusian sebuah use case atau operasi tertentu.

\subsection{Pengadaan Barang dan jasa}

Pasal 1 ayat 1 peraturan presiden No. 54 tahun 2010 sebagaimana diubah terakhir dengan peraturan presiden No. 70 tahun 2012 tentang pengadaan barang atau jasa pemerintah adalah kegiatan untuk memperoleh barang atau jasa oleh kementrian atau lembaga atau satuan kerja perangkat daerah atau institusi lainnya yang prosesnya dimulai dari perencanaan kebutuhan sampai diselesaikannya seluruh kegiatan untuk memperoleh barang atau jasa.

\section{METODE PENELITIAN (Research Method)}

Metodologi penelitian yang digunakan dalam penelitian ini menggunakan Design Science Research Methodology (DSRM). Penggunaan metodologi ini difokuskan pada solusi permasalahan dan pengembangan system. [14] 


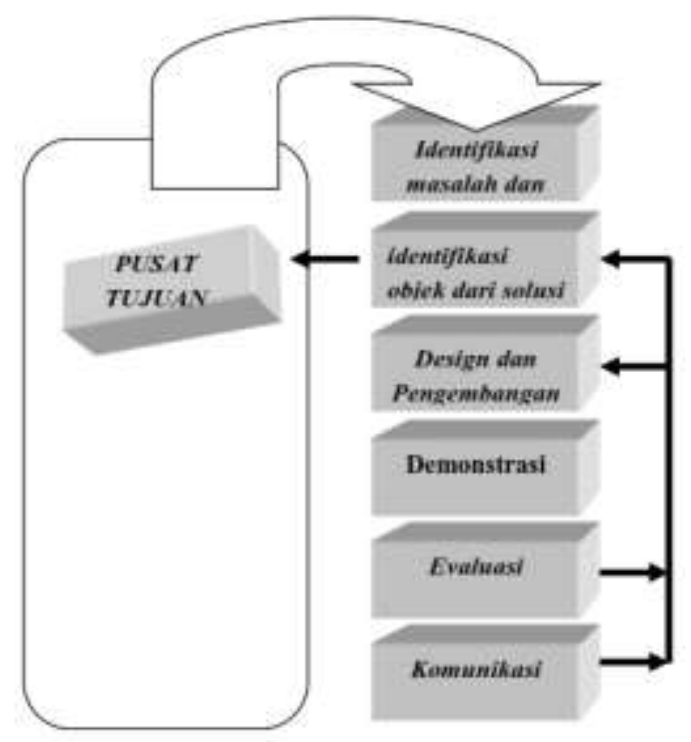

Gambar 2. Tahapan Metodologi Penelitian

1. Identifikasi Masalah dan Motivasi

Melakukan identifikasi masalah yang terjadi pada penelitian dengan beberapa teknik pengumpulan data yaitu wawancara. Dalam hal ini adalah mengidentifikasi semua proses bisnis yang terjadi pada Pemerintah Daerah Kabupaten Karawang bagian Pengadaan Barang dan Jasa. Untuk membangun system berbasis layanan. Pada tahapan ini merupakan titik awal penelitian. Semua proses bisnis akan dirangkum dan didapatkan solusi dan dikonsepkan sesuai dengan proses bisnis yang terjadi di organisasi.

2. Mendefinisikan Obyek dari Solusi Permasalahan

Pada tahapan ini mendefinisikan solusi dari permasalahan dengan melakukan studi literatur, untuk memperoleh teori-teori dan konsep dari metode yang digunakan yaitu

3. Design dan Pengembangan

Tahapan ini dilakukan Design berupa rancangan dan model dari Analisa yang dilakukan pada tahap sebelumnya. Selanjutnya akan dilakukan pengembangan dengan Use Case Diagram untuk proses alur system aplikasi, Activity Diagram, Sequence Diagram dan Class Diagram. [13]

4. Demonstrasi (Implementasi)

Tahap ini melakukan Implementasi terhadap rancangan pengembangan. Pada pase ini merupakan pase pengkodingan kedalam teknologi yang digunakan untuk membuat aplikasi pengadaan barang dan jasa berbasis web.

5. Evaluasi

Setelah Implementasi dilakukan untuk mengganalisa dari model yang dibuat, selanjutnya data hasil analisa akan dilakukan pengujian dengan Black Box. [15]

6. Komunikasi

Komunikasi pada tahapan ini adalah bentuk laporan dari hasil penelitian yang berupa sebuah kesimpulan untuk dipublikasikan. Isi kesimpulan tersebut dapat berupa penilaian terhadap model yang telah dibuat dan hasil analisis dari bentuk pemodelan yang telah ujikan.

\section{HASIL DAN PEMBAHASAN (Results and Analysis)}

\subsection{Analisis Sistem Berjalan}

Analisa sistem berjalan dapat diuraikan sebagai berikut : 
DOI: $10.52362 / j m i j a y a k a r t a . v 1 i 4.547$

1. Administrator menerima laporan realisasi pengadaan barang dan jasa dari POKJA (Kelompok Kerja) bagian pengadaan barang dan jasa.

2. Administrator memberikan laporan realisasi pengadaan barang dan jasa kepada kepala bagian pengadaan barang dan jasa.

3. Kepala bagian melakukan pengecekan laporan pengadaan barang dan jasa jika lulus pengecekan maka laporan akan disimpan di lemari penyimpanan, jika laporan tidak lulus maka laporan akan disimpan pada map berkas berbeda.

Analisa sistem berjalan digambarkan pada gambar flowchart di bawah ini :

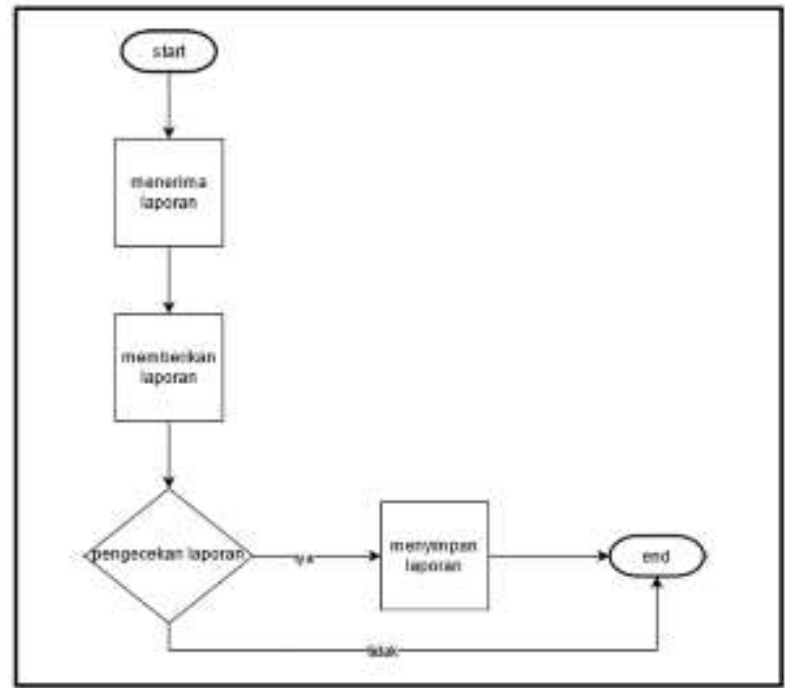

Gambar 3. Analisis Sistem Yang Berjalan

\subsection{Use Case Diagram}

Pada sistem informasi laporan realisasi pengadaan barang dan jasa di Pemerintah Daerah Kabupaten Karawang Bagian Pengadaan Barang dan Jasa terdapat use case diagram yang bertujuan untuk mendeskripsikan tahapan-tahapan dan menggambarkan tindakan apa saja yang dapat aktor lakukan terhadap sistem informasi laporan realisasi pengadaan barang dan jasa.

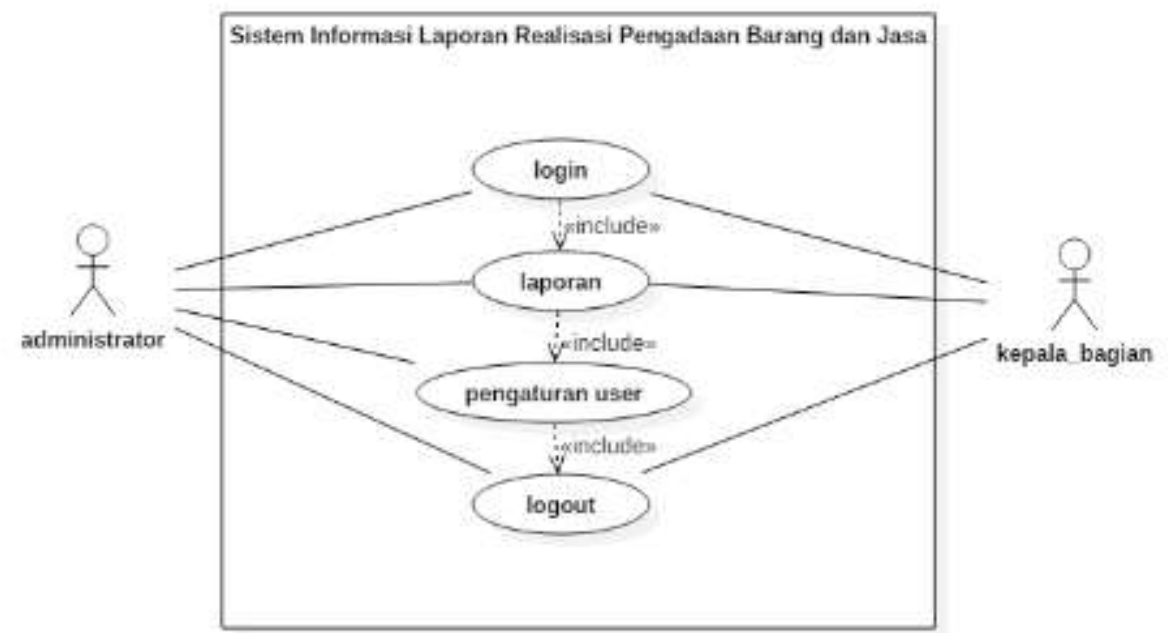

Gambar 4. Use Case Diagram Admin 


\section{Tabel Definisi Aktor}

Berikut adalah definisi aktor yang ada di dalam sistem informasi laporan realisasi pengadaan barang dan jasa. Pada sistem ini terdiri dari dua aktor, yang di paparkan dalam tabel berikut antara lain :

Tabel 1. Definisi Aktor

\begin{tabular}{c|l|l}
\hline No. & \multicolumn{1}{|c|}{ Aktor } & \multicolumn{1}{c}{ Keterangan } \\
\hline 1. & Administrator & $\begin{array}{l}\text { Pengguna dengan hak akses penuh } \\
\text { dalam sistem informasi. }\end{array}$ \\
\hline 2. & Kepala Bagian & $\begin{array}{l}\text { Pengguna yang hanya dapat melihat } \\
\text { dan memperivikasi laporan pengadaan } \\
\text { barang dan jasa. }\end{array}$ \\
\hline
\end{tabular}

\section{Tabel Definisi Use Case}

Berikut adalah definisi use case yang digunakan dalam sistem informasi laporan realisasi pengadaan barang dan jasa yaitu :

Tabel 2. Definisi Use Case

\begin{tabular}{|c|c|c|}
\hline No. & Use Case & Deskripsi \\
\hline 1. & Login & $\begin{array}{l}\text { Merupakan proses masuk ke dalam } \\
\text { sistem informasi dengan memasukkan } \\
\text { username dan password untuk } \\
\text { mendapatkan hak akses. }\end{array}$ \\
\hline 2. & Laporan & $\begin{array}{l}\text { Merupakan laporan realiasasi } \\
\text { pengadaan barang dan jasa. }\end{array}$ \\
\hline 3. & Pengaturan User & Merupakan proses penambahan user. \\
\hline 4. & Logout & $\begin{array}{l}\text { Merupakan proses keluar dari sistem } \\
\text { informasi. }\end{array}$ \\
\hline
\end{tabular}

\section{Skenario Use Case Laporan}

Tabel 3. Skenario Use Case Laporan

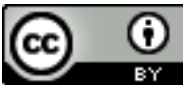

This work is licensed under a Creative Commons Attribution 4.0 International License.

http://journal.stmikjayakarta.ac.id/index.php/JMIJayakarta 


\begin{tabular}{|c|c|c|c|c|}
\hline Nama Use Case & \multicolumn{4}{|c|}{ Laporan } \\
\hline $\begin{array}{l}\text { Skenario Deskripsi } \\
\text { Singkat }\end{array}$ & \multicolumn{4}{|c|}{$\begin{array}{l}\text { Sistem akan menampilkan laporan, tambah, ubah, dan hapus } \\
\text { laporan }\end{array}$} \\
\hline Aktor & \multicolumn{4}{|c|}{ Administrator dan Kepala Bagian } \\
\hline Kondisi Sebelum & \multicolumn{4}{|l|}{-} \\
\hline Kondisi Sesudah & \multicolumn{4}{|c|}{$\begin{array}{l}\text { Adanya perubahan data yang tersimpan ke dalam database } \\
\text { sistem }\end{array}$} \\
\hline \multirow[t]{3}{*}{ Aliran Aktivitas } & & Aktor & & Sistem \\
\hline & 1. & $\begin{array}{l}\text { Memilih menu } \\
\text { laporan }\end{array}$ & 1. & Menampilkan laporan \\
\hline & 2. & Menambah laporan & 2. & $\begin{array}{l}\text { Menampilkan form } \\
\text { tambah laporan }\end{array}$ \\
\hline
\end{tabular}

\section{Activity Diagram Login}

Activity diagram di bawah ini digunakan untuk mengetahui alur login. Berikut ini activity diagram untuk login :

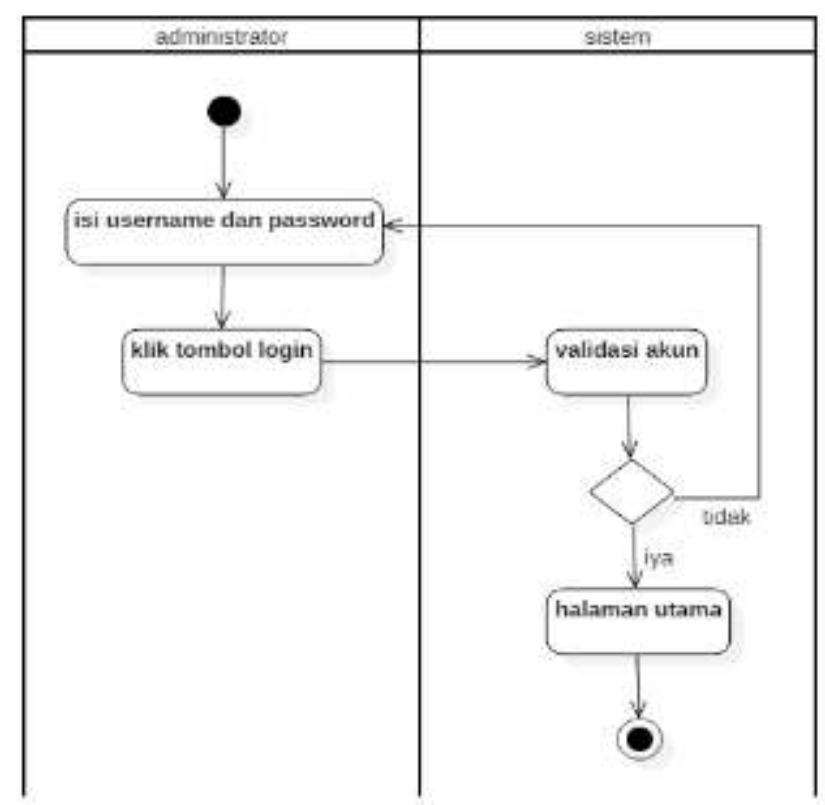

Gambar 5. Activity Diagram Login

\section{Activity Diagram Laporan}

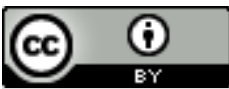

This work is licensed under a Creative Commons Attribution 4.0 International License.

http://journal.stmikjayakarta.ac.id/index.php/JMIJayakarta 
DOI: $10.52362 / j m i j a y a k a r t a . v 1 i 4.547$

Activity diagram di bawah ini digunakan untuk mengetahui alur data laporan. Berikut ini activity diagram untuk laporan:

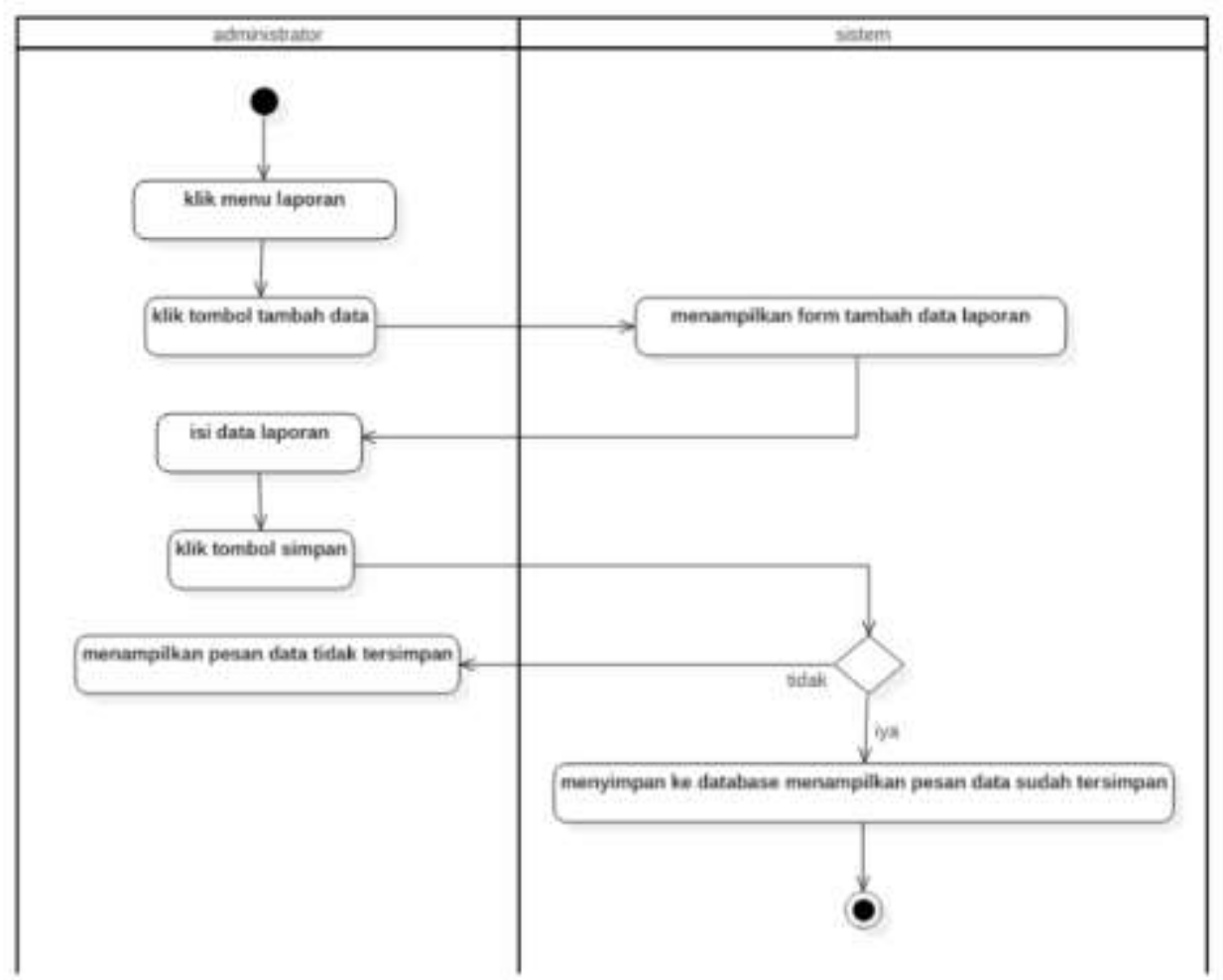

Gambar 6. Activity Diagram Laporan

\section{Class Diagram}


DOI: $10.52362 / j m i j a y a k a r t a . v 1 i 4.547$

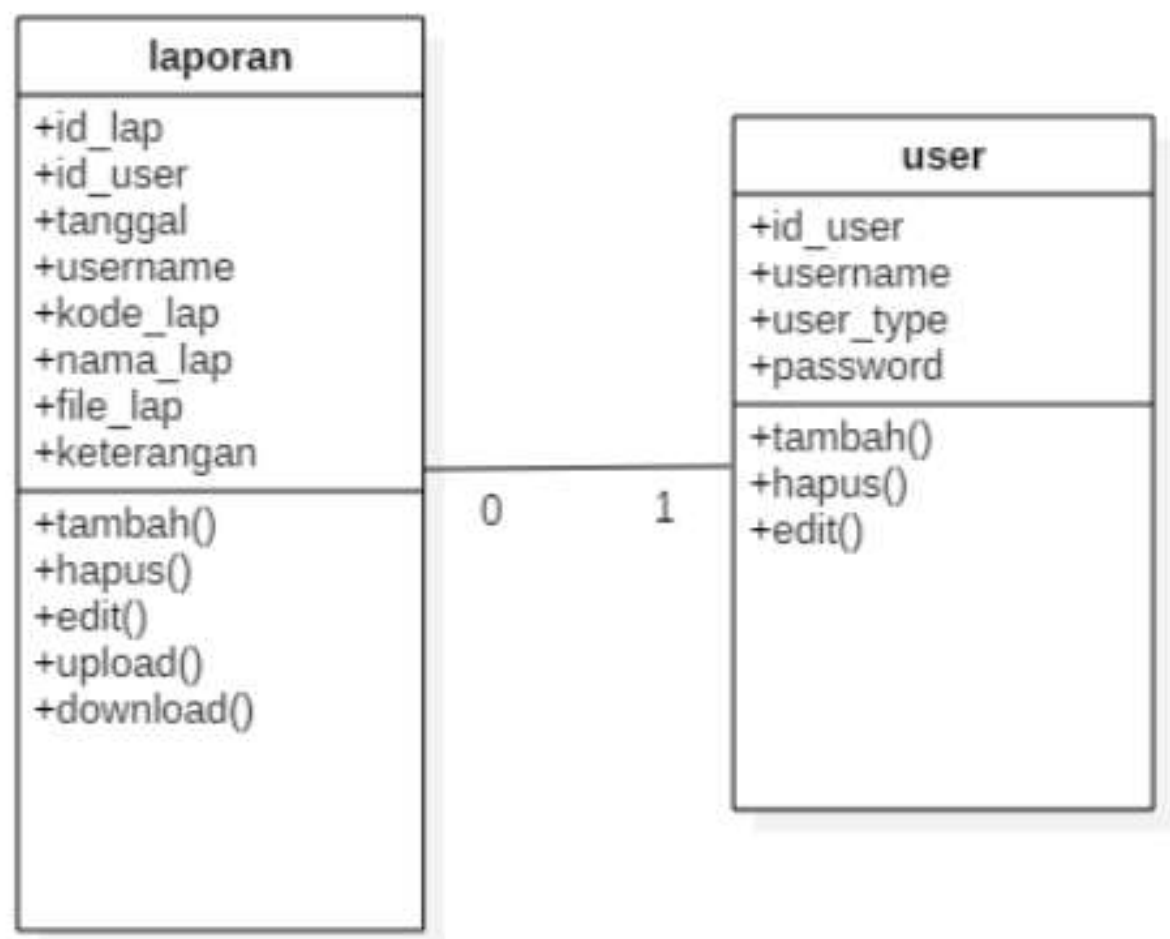

Gambar 7. Class Diagram

\section{Rancangan Halaman Utama}




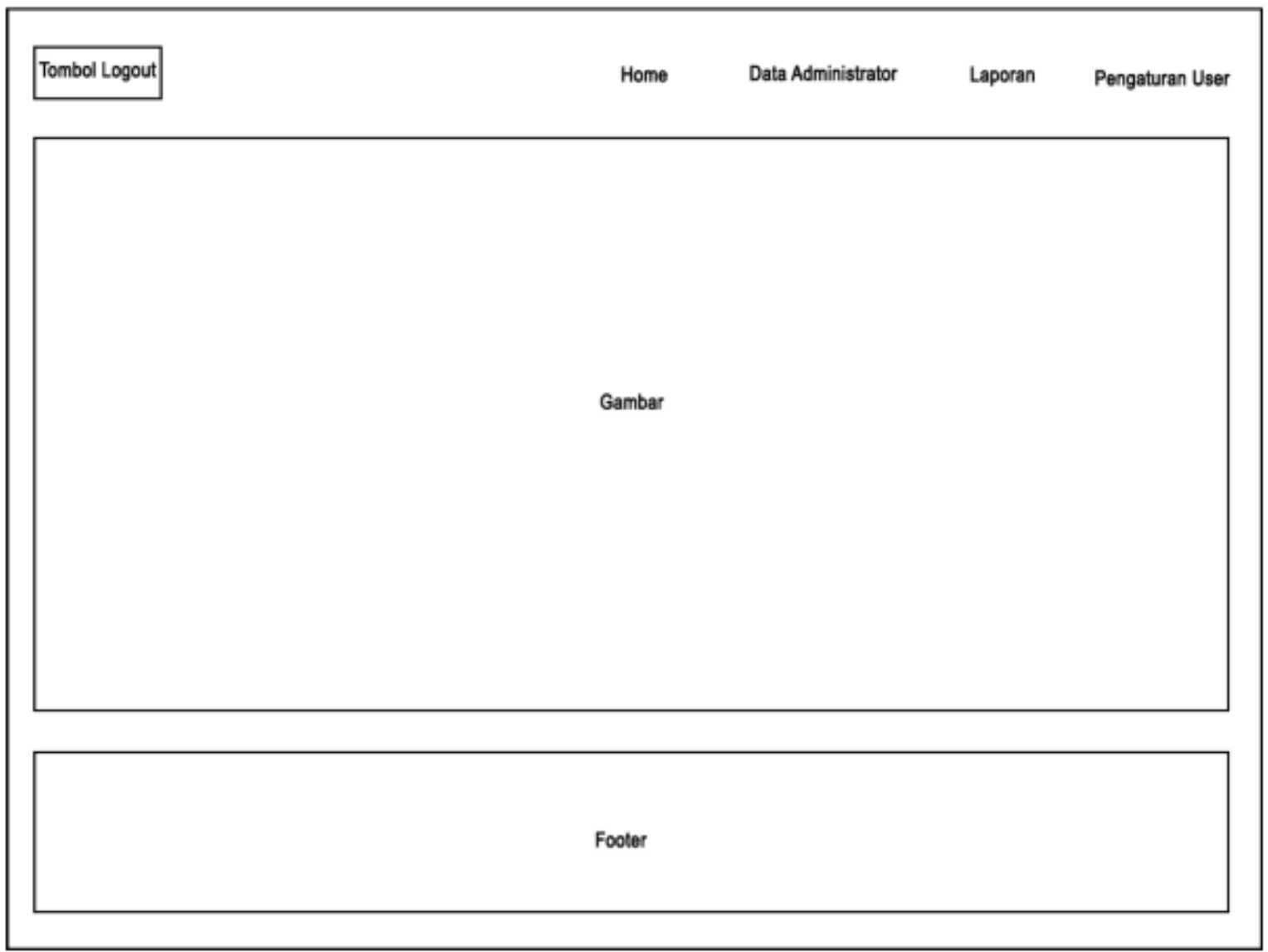

Gambar 8. Halaman Utama Admin

\subsection{Implementasi}

Tahap implementasi merupakan tahapan lanjutan dari tahap perancangan, analisis, dan desain sistem yang bertujuan menerapkan sistem yang telah dirancang pada tahap sebelumnya baik perangkat lunak maupun perangkat keras yang digunakan. Berikut ini merupakan perangkat yang digunakan untuk merancang dan mengimplementasikan sistem informasi laporan realisasi pengadaan barang dan jasa :

1. perangkat keras atau hardware;

2. perangkat lunak atau software;

3. pengguna atau user;

\subsection{Implementasi Antarmuka}

Implementasi antarmuka merupakan tahap pengimplementasian dari tahap desain dan analisis sistem. Berikut ini adalah implementasi antarmuka dari system informasi laporan realisasi pengadaan barang dan jasa :

\section{Halaman Login}




\section{CUKPBJ}

Username

\section{Halaman Home}

Gambar 9. Halaman Login

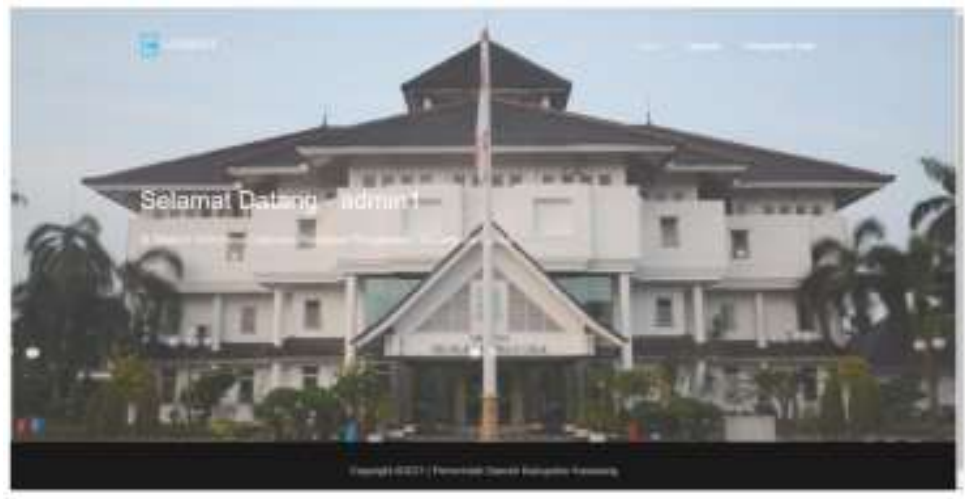

Gambar 10. Halaman Home

\section{Halaman laporan}

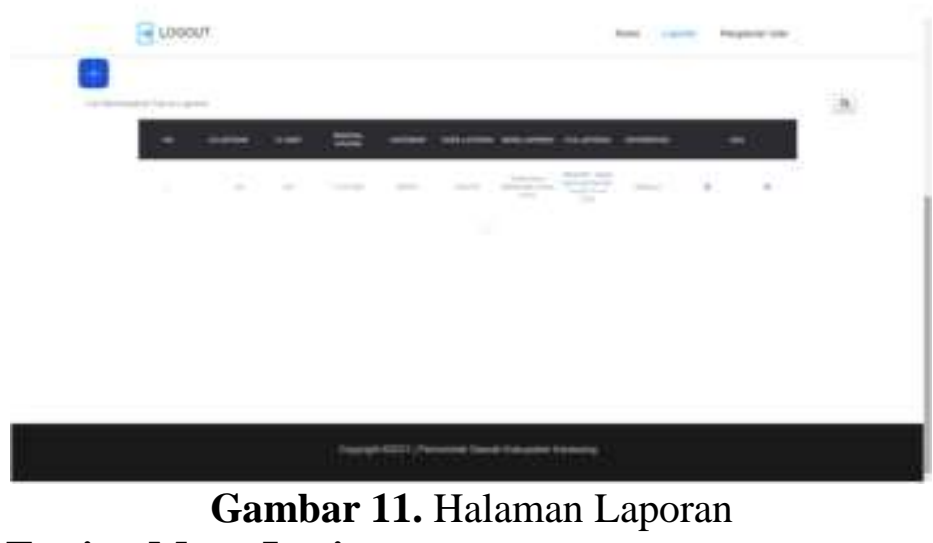

\section{Black Box Testing Menu Login}

Black box testing berfokus pada spesifikasi fungsional dari perangkat lunak, kumpulan kondisi input dan melakukan pengetesan pada fungsional program.

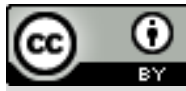

This work is licensed under a Creative Commons Attribution 4.0 International License. http://journal.stmikjayakarta.ac.id/index.php/JMIJayakarta 


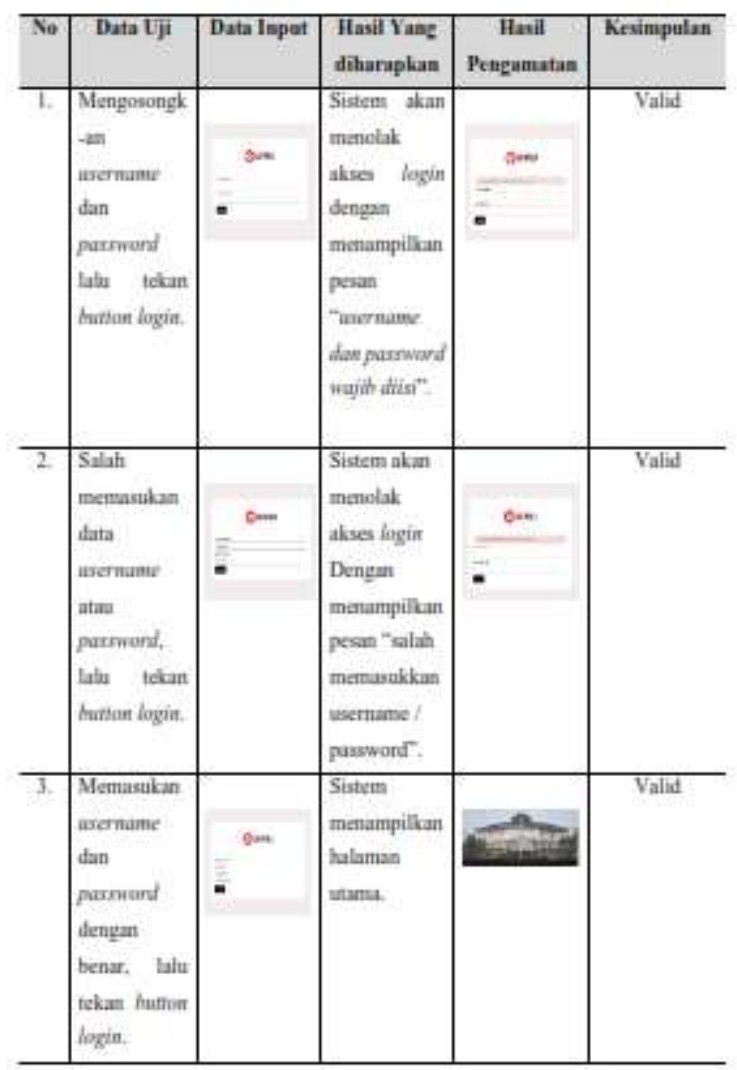

Gambar 12. Black Box Testing Menu Login

\section{KESIMPULAN (Conclusion)}

\subsection{Kesimpulan}

Berdasarkan uraian penjelasan dan hasil penelitian di atas, maka dapat ditarik kesimpulan bahwa

1. Sistem informasi laporan realisasi pengadaan barang dan jasa dapat mempermudah dalam pencarian dan penyajian laporan realisasi pengadaan barang dan jasa.

2. Sistem informasi laporan realisasi pengadaan barang dan jasa dapat mempermudah admin untuk menyimpan laporan realisasi pengadaan barang dan jasa.

\subsection{Saran}

Adapun saran yang dikemukakan sehubungan dengan sistem informasi yang dirancang ialah sebagai berikut :

3. Sistem informasi laporan realisasi pengadaan barang dan jasa berbasis web dapat terus dikembangkan supaya fitur-fitur yang terdapat di dalamnya dapat ditambahkan sesuai dengan kebutuhan di Pemerintah Daerah Kabupaten Karawang Bagian Pengadaan Barang dan Jasa.

4. Mengingat pengguna yang belum terbiasa menggunakan sistem informasi yang bersifat komputerisasi, maka pihak Pemerintah Daerah Kabupaten Karawang Bagian Pengadaan Barang dan Jasa perlu mengadakan training kepada pengguna sistem informasi ini yaitu administrator dan kepala bagian.

\section{REFERENSI (Reference)}

[1] B. Unhelkar, Software engineering with UML. 2017.

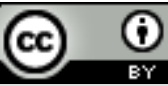

This work is licensed under a Creative Commons Attribution 4.0 International License.

http://journal.stmikjayakarta.ac.id/index.php/JMIJayakarta 
DOI: $10.52362 / j m i j a y a k a r t a . v 1 i 4.547$

[2] Mulyadi, "Sistem Akuntasi," Salemba Empat, 2016.

[3] Abdul Kadir, "Pengenalan Sistem Informasi Edisi Revisi,” Edisi Revisi. 2014.

[4] Fathansyah, Basis Data. Bandung: Informatika, 2015.

[5] J. Enterprise, MySQL untuk Pemula. Jakarta: PT Elex Media Komputindo, 2014.

[6] M. R. Arief, Pemrograman Web Dinamis Menggunakan PHP dan MySQL. 2012.

[7] J. Enterprise, Membuat Website PHP dengan Codeigniter. Jakarta: PT Elex Media Komputindo, 2015.

[8] A. Basuki, Membangun Aplikasi SMS Gateway berbasis Web dengan Codeingniter dan Bootstrap. Yogyakarta: Lokomedia, 2019.

[9] J. Enterprise, PHP Komplet. Jakarta: PT Elex Media Komputindo, 2017.

[10] E. Ratnasari, "Pengertian Dan Fungsi Xampp,” Ilmuti.Org, 2018.

[11] Z. A. R. \& S. Community, Bootstrap Design Framework. Jakarta: PT Elex Media Komputindo, 2015.

[12] D. T. Hoang, O. Chernomor, A. Von Haeseler, B. Q. Minh, and L. S. Vinh, "UFBoot2: Improving the ultrafast bootstrap approximation," Mol. Biol. Evol., vol. 35, no. 2, 2018, doi: $10.1093 / \mathrm{molbev} / \mathrm{msx} 281$.

[13] B. Rumpe, Agile Modeling with UML. 2017.

[14] N. H. Thuan, A. Drechsler, and P. Antunes, "Construction of design science research questions," Commun. Assoc. Inf. Syst., vol. 44, no. 1, 2019, doi: 10.17705/1CAIS.04420.

[15] T. S. Jaya, "Pengujian Aplikasi Dengan Metode Blackbox Testing Boundary Value Analysis (Studi Kasus: Kantor Digital Politeknik Negeri Lampung)," J. Inform. J. Pengemb. IT, vol. 3, no. 2, 2018. 